\title{
SYNTHESIS AND PROPERTIES OF PARTIALLY HYDROGENATED ETHYL ([3,4']BIPYRIDIN-6'-YLSULFANYL) ACETATES
}

\author{
A. Krauze, Z. Andžāns, G. Duburs \\ Latvian Institute of Organic Synthesis, Aizkraukles str. 21, Riga, LV-1006, Latvia; \\ e-mail: krauze@osi.lv
}

Ethyl 2'-hydroxy-1',2',3',4'-tetrahydro[3,4']bipyridine-3'-carbo-xylate $\mathbf{3}$ and the corresponding ethyl 1',4'-dihydro[3,4']bipyridine-3'-carboxylate 4 as potential cardiovascular agents have been prepared by alkylation of 2'-hydroxy-1',2',3',4'-tetrahydro[3,4']bipyridine-6'-thiolate $\mathbf{1}$ or betaine 2 with ethyl bromoacetate. The treatment of $[3,4$ '] bipyridine 4 with $\mathrm{KOH} / \mathrm{H}_{2} \mathrm{O}$ gave diethyl 3-amino-4-(pyridin-3-yl)-4,7-dihydrothieno[2,3b]-pyridine-2,5-dicarboxylate $\mathbf{5}$, but subsequent treatment of the remaining reaction mixture with acetic acid excess gave ethyl 3-oxo7-(pyridin-3-yl)-2,3-dihydro-7H-thiazolo[3,2-a]pyridine-6-carboxylate 7 the product of intramolecular acylation. Compounds 4,5 and 7 have been prepared using the one-pot synthesis method. Alkylation of [3,4']bipyridine 4 with iodomethane gave 1',4'-dihydro[3,4'] bipyridin-1-ium iodide 8 .

Key words: [3,4']bipyridine, piperidinium pyridine-6-thiolate, $7 H$ thiazolo[3,2-a]pyridine, thieno[2,3-b]pyridine, [3,4']bipyridin-1-ium iodide.

\section{INTRODUCTION}

6-Alkylsulfanyl-1,4-dihydropyridines (DHPs) display antihypertensive and vasodilating [1-3], hepatoprotective [4], antioxidant [5], and antiradical [6] activities, however, the biological activities of these compounds in comparison with DHPs not containing sulfur atom are still insufficiently studied.

On the other hand, [3,4']bipyridines are of interest as cardiotonic agents [7] for more than 25 years. Among them milrinone, phosphodiesterase III inhibitor, is non-catecholamine, non-glycoside drug that is not associated with $\beta$-adrenergic receptors or plasma catecholamine concentrations [8-10]. Recently compounds and pharmaceutical compositions for treatment of myosin heavy chain mediated diseases, and in particular, heart failure, have been found in series of 3-acetyl-6benzoylsulfanyl-1,4-DHPs [11]. The potential cardiotonics - 1',4'-dihydro[3,4']bipyridines bearing carbamoylmethylsulfanyl substituent in position $6^{\prime}$ appeared to be not enough soluble and lipophilic [12].

To improve cardiovascular activity of the low-toxic 4-aryl-5-cyano-2-methyl-6-methylsulfanyl-1,4-DHP-3-carboxylates [3], lipophilicity was optimized by introducing another ester group in the 1,4-DHP molecule [13], which is in agreement with general observations for DHPs series [14].

Partially hydrogenated ethyl (5'-ethoxycarbonyl[3,4']bipyridin-6'-ylsulfanyl) acetates bearing two ester groups could be interesting from this point of view as potential cardiotonics.

\section{EXPERIMENTAL}

Melting points were determined on a Boetius apparatus and were used uncorrected. IR spectra were recorded on a Perkin-Elmer $580 \mathrm{~B}$ spectrometer 
(in nujol) and peak positions $v_{\max }$ were measured in $\mathrm{cm}^{-1}$. NMR spectra were recorded on a Varian Mercury 200 spectrometer using hexamethyldisiloxane (HMDSO) as internal standard. The course of the reactions and the individuality of substances were monitored by TLC on Kieselgel $60 \mathrm{~F}$ Merck plates with dichloromethane - hexane - acetone $(2: 1: 1)$ as eluent. Synthesis of piperidinium 1',2',3',4'-tetrahydrobipyridine-6'-thiolate 1 (yield 72\%) and betaine 2 (yield $80 \%$ ) is described in [12]. Compounds were recrystallized from ethanol.

Ethyl 5'-cyano-6'-ethoxycarbonylmethylsulfanyl-2'-hydroxy-

\section{2'-phenyl-1',2',3',4'-tetrahydro[3,4']bipyridine-3'-carboxylate (3)}

Mixture of piperidinium 1',2',3',4'-tetrahydrobipyridine-6'-thiolate1[12] (4.67 g, $10 \mathrm{mmol}$ ) and ethyl bromoacetate $(1.10 \mathrm{ml}, 10 \mathrm{mmol})$ in $20 \mathrm{ml}$ of ethanol was shortly heated until dissolution, stirred for $30 \mathrm{~min}$ at ambient temperature, and water $(2 \mathrm{ml})$ was added. The precipitate was filtered, washed with ethanol $(5 \mathrm{ml})$ and water $(20 \mathrm{ml})$ to give $3.83 \mathrm{~g}(82 \%)$ of compound 3 as colourless powder; mp $172-174{ }^{\circ} \mathrm{C}$. IR spectrum, $v, \mathrm{~cm}^{-1}: 1700,1738(\mathrm{C}=\mathrm{O}) ; 2201(\mathrm{C} \equiv \mathrm{N})$; 3282, $3456(\mathrm{NH}, \mathrm{OH}) ;{ }^{1} \mathrm{H}$ NMR spectrum $\left(\mathrm{DMSO}_{6} ; \delta, \mathrm{ppm}\right): 0.40$ and 3.35 $\left(5 \mathrm{H}, \mathrm{t}\right.$ and $\left.\mathrm{q}, J=7.0 \mathrm{~Hz}, 3^{\prime}-\mathrm{COOEt}\right) ; 1.17$ and $4.11\left(5 \mathrm{H}, \mathrm{t}\right.$ and $\mathrm{q}, J=7.0 \mathrm{~Hz}, 6^{\prime}-$ $\left.\mathrm{SCH}_{2} \mathrm{COOEt}\right) ; 2.90$ and $4.12\left(2 \mathrm{H}, \mathrm{d}\right.$ and d, $J=12.1 \mathrm{~Hz}, 3^{\prime}-\mathrm{H}$ and $\left.4^{\prime}-\mathrm{H}\right) ; 3.86$ and $3.97\left(2 \mathrm{H}, \mathrm{d}\right.$ and d, $\left.J=15.7 \mathrm{~Hz}, \mathrm{SCH}_{2}\right) ; 6.49(1 \mathrm{H}, \mathrm{s}, \mathrm{OH}) ; 7.27-8.40(9 \mathrm{H}, \mathrm{m}$, 2'- $\mathrm{C}_{6} \mathrm{H}_{5}$ and 2-, 4-, 5- and 6-H); $8.08(1 \mathrm{H}, \mathrm{s}, \mathrm{NH})$. Found, \%: C 61.30; H 5.44; $\mathrm{N}$ 8.83; $\mathrm{S}$ 6.72. Calculated for $\mathrm{C}_{24} \mathrm{H}_{25} \mathrm{~N}_{3} \mathrm{O}_{5} \mathrm{~S}$, \%: C 61.66; H 5.39; N 8.99; $\mathrm{S} 6.86$.<smiles>CCC1C(c2ccccc2)C(C)=C(F)N[C@]1(C)O</smiles>

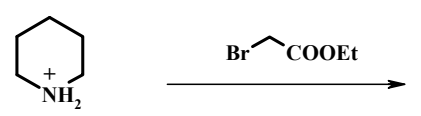<smiles>CCCCNC1=C(C)C(c2cccnc2)C(CC)C(C)(C)C1(C)C</smiles><smiles>CCCC</smiles><smiles>Cc1nc(F)c(C)c(-c2cccnc2)c1O</smiles>

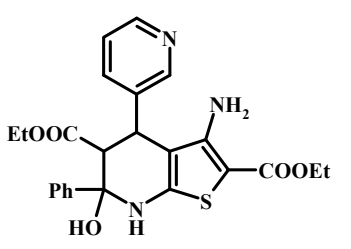

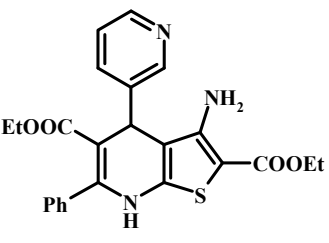

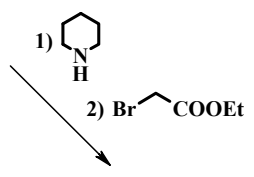

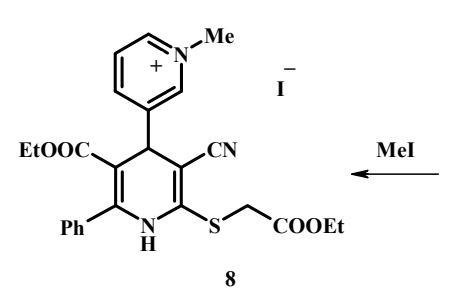

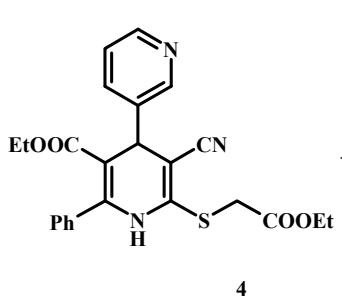<smiles>COCC1=C(C)C(=O)C(C)=C(C)C1c1cccnc1</smiles> 
One-pot reactions of betaine 2 with ethyl bromoacetate, potassium hydroxide and acetic acid

To the suspension of betaine 2 [12] (3.63 g, $10 \mathrm{mmol})$ in $10 \mathrm{ml}$ of ethanol, piperidine $(1.0 \mathrm{ml}, 10 \mathrm{mmol})$ and ethyl bromoacetate $(1.10 \mathrm{ml}, 10 \mathrm{mmol})$ were added, the mixture was shortly heated until dissolution, stirred for $30 \mathrm{~min}$ at ambient temperature, and water $(20 \mathrm{ml})$ was added. The reaction mixture was treated with $10 \mathrm{ml}$ of $2 \mathrm{~N}$ potassium hydroxide solution, refluxed for $5 \mathrm{~min}$, cooled to $\sim 0{ }^{\circ} \mathrm{C}$ and precipitate was filtered, washed with ethanol $(5 \mathrm{ml})$ and water $(20 \mathrm{ml})$ to give $0.55 \mathrm{~g}(12 \%)$ of diethyl 3-amino-6-phenyl-4-(pyridin-3yl)-4,7-dihydrothieno[2,3-b]pyridine-2,5-dicarboxylate (5) as slightly yellow powder; mp 200-203 ${ }^{\circ} \mathrm{C}$. IR spectrum, $v, \mathrm{~cm}^{-1}$ : 1650, $1660(\mathrm{C}=\mathrm{O}) ; 3320,3460$ $\left(\mathrm{NH}, \mathrm{NH}_{2}\right) ;{ }^{1} \mathrm{H}$ NMR spectrum (DMSO-d $\left.\mathrm{d}_{6} ; \delta, \mathrm{ppm}\right): 0.63$ and $3.61(5 \mathrm{H}, \mathrm{t}$ and $\mathrm{q}$, $J=7.0 \mathrm{~Hz}, 5$-COOEt); 1.13 and $4.05(5 \mathrm{H}, \mathrm{t}$ and q, $J=7.0 \mathrm{~Hz}, 2$-COOEt); 5.16 $(1 \mathrm{H}, \mathrm{s}, 4-\mathrm{H}) ; 6.38\left(2 \mathrm{H}, \mathrm{s}, \mathrm{NH}_{2}\right) ; 7.24-8.60\left(9 \mathrm{H}, \mathrm{m}, 6-\mathrm{C}_{6} \mathrm{H}_{5}\right.$ and $\left.4-\mathrm{C}_{5} \mathrm{H}_{4} \mathrm{~N}\right) ; 10.05$ $(1 \mathrm{H}, \mathrm{s}, \mathrm{NH})$. Found, \%: C 63.70; H 5.27; N 9.20; S 7.28. Calculated for $\mathrm{C}_{24} \mathrm{H}_{23} \mathrm{~N}_{3} \mathrm{O}_{4} \mathrm{~S}, \%$ : C 64.13; H 5.16; N 9.35; S 7.13.

The remaining reaction mixture was refluxed for 5 min with $2 \mathrm{ml}$ of acetic acid, cooled to $\sim 10{ }^{\circ} \mathrm{C}$ and precipitate was filtered, washed with ethanol $(5 \mathrm{ml})$ and water $(20 \mathrm{ml})$ to give $1.05 \mathrm{~g}(23 \%)$ of ethyl 5'-cyano-6'-ethoxycarbonylmethylsulfanyl-2'-phenyl-1',4'-dihydro-[3,4']bipyridine-3'-carboxy-late (4) as slightly yellow powder; $\mathrm{mp} 128-129{ }^{\circ} \mathrm{C}$. IR spectrum, $\mathrm{v}, \mathrm{cm}^{-1}: 1684,1735$ $(\mathrm{C}=\mathrm{O}) ; 2198(\mathrm{C} \equiv \mathrm{N}) ; 3148,3240(\mathrm{NH}) ;{ }^{1} \mathrm{H}$ NMR spectrum (DMSO-d $\left.\mathrm{d}_{6} ; \delta, \mathrm{ppm}\right)$ : 0.65 and $3.65\left(5 \mathrm{H}, \mathrm{t}\right.$ and q, $\left.J=7.0 \mathrm{~Hz}, 3^{\prime}-\mathrm{COOEt}\right) ; 1.14$ and $4.07(5 \mathrm{H}, \mathrm{t}$ and q, $\left.J=7.0 \mathrm{~Hz}, 6{ }^{\prime}-\mathrm{SCH}_{2} \mathrm{COOEt}\right) ; 3.79$ and $4.05\left(2 \mathrm{H}, \mathrm{d}\right.$ and $\left.\mathrm{d}, J=15.3 \mathrm{~Hz}, \mathrm{SCH}_{2}\right)$; $4.58\left(1 \mathrm{H}, \mathrm{s}, 4{ }^{\prime}-\mathrm{H}\right) ; 7.27-8.46\left(9 \mathrm{H}, \mathrm{m}, 2^{\prime}-\mathrm{C}_{6} \mathrm{H}_{5}\right.$ and 2-, 4-, 5- and 6- $\left.\mathrm{H}\right) ; 9.98(1 \mathrm{H}$, $\mathrm{s}, \mathrm{NH})$. Found, \%: C 63.90; H 5.14; $\mathrm{N}$ 9.27; $\mathrm{S} 7.18$. Calculated for $\mathrm{C}_{24} \mathrm{H}_{23} \mathrm{~N}_{3} \mathrm{O}_{4} \mathrm{~S}, \%$ : C 64.13; H 5.16; N 9.35; $\mathrm{S}$ 7.13.

The remaining second filtrate was refluxed for $5 \mathrm{~h}$ with $2 \mathrm{ml}$ of acetic acid, cooled to $\sim 10{ }^{\circ} \mathrm{C}$ and precipitate was filtered, washed with ethanol $(5 \mathrm{ml})$ to give $0.20 \mathrm{~g}(5 \%)$ of ethyl 8-cyano-3-oxo-5-phenyl-7-(pyridin-3-yl)-2,3-dihydro-7H-thiazolo[3,2-a]pyridine-6-carboxylate (7) as slightly yellow powder; mp 168-170 ${ }^{\circ} \mathrm{C}$ [15]. IR spectrum, $v, \mathrm{~cm}^{-1}: 1672,1757(\mathrm{C}=\mathrm{O}) ; 2206$ $(\mathrm{C} \equiv \mathrm{N}) ;{ }^{1} \mathrm{H}$ NMR spectrum (DMSO- $\left.\mathrm{d}_{6} ; \delta, \mathrm{ppm}\right): 0.53$ and $3.52(5 \mathrm{H}, \mathrm{t}$ and $\mathrm{q}$, $J=7.0 \mathrm{~Hz}, 6$-COOEt); 3.97 and $4.04\left(2 \mathrm{H}, \mathrm{d}\right.$ and d, $\left.J=17.2 \mathrm{~Hz}, 2-\mathrm{CH}_{2}\right) ; 4.80$ $(1 \mathrm{H}, \mathrm{s}, 7-\mathrm{H}) ; 7.24-8.54\left(9 \mathrm{H}, \mathrm{m}, 5-\mathrm{C}_{6} \mathrm{H}_{5}\right.$ and $\left.7-\mathrm{C}_{5} \mathrm{H}_{4} \mathrm{~N}\right)$.

Treatment of pure ethyl 5'-cyano-6'-ethoxycarbonylmethylsulfanyl2'-phenyl-1',4'-dihydro[3,4']bipyridine-3'-carboxylate (4) with $\mathrm{KOH}$

Mixture of carboxylate $4(0.31 \mathrm{~g}, 0.69 \mathrm{mmol})$ and $\mathrm{KOH}(0.04 \mathrm{~g}, 0.71 \mathrm{mmol})$ in $10 \mathrm{ml}$ of absolute ethanol was refluxed for $5 \mathrm{~min}$, cooled to $\sim 10{ }^{\circ} \mathrm{C}$ and precipitate was filtered, washed with ethanol $(2 \mathrm{ml})$ and water $(10 \mathrm{ml})$ to give $0.24 \mathrm{~g}(79 \%)$ of diethyl 4,7-dihydrothieno[2,3-b]pyridine-2,5-dicarboxylate (5).

\section{5'-Cyano-3'-ethoxycarbonyl-6'-ethoxycarbonylmethylsulfanyl- \\ 1-methyl-2'-phenyl-1',4'-dihydro[3,4']bipyridin-1-ium iodide (8)}

Mixture of 1',4'-dihydro-[3,4']bipyridine-3'-carboxylate 4 (0.23 g, $0.5 \mathrm{mmol})$ and iodomethane $(0.62 \mathrm{ml}, 10 \mathrm{mmol})$ in $10 \mathrm{ml}$ of acetone was refluxed for $5 \mathrm{~h}$, the reaction mixture was evaporated to dry and treated with $10 \mathrm{ml}$ of ethanol. The precipitated crystals were filtered to give $0.22 \mathrm{~g}$ (74\%) of 1-methyl-1',4'- 
dihydro $[\mathbf{3 , 4}$ ' $]$ bipyridin-1-ium iodide 8 as yellow powder; mp $95-98{ }^{\circ} \mathrm{C}$. IR spectrum, $v, \mathrm{~cm}^{-1}: 1635,1676,1720(\mathrm{C}=\mathrm{O}) ; 2201(\mathrm{C} \equiv \mathrm{N}) ; 3250(\mathrm{NH}) .{ }^{1} \mathrm{H}$ NMR spectrum (DMSO-d $\left.\mathrm{d}_{6} ; \delta, \mathrm{ppm}\right): 0.64$ and $3.66\left(5 \mathrm{H}, \mathrm{t}\right.$ and $\mathrm{q}, J=7.0 \mathrm{~Hz}, 3^{\prime}-$ COOEt); 1.15 and 4.09 (5H, t and q, $\left.J=7.0 \mathrm{~Hz}, 6^{\prime}-\mathrm{SCH}_{2} \mathrm{COOEt}\right) ; 3.82$ and 4.08 $\left(2 \mathrm{H}, \mathrm{d}\right.$ and d, $\left.J=15.3 \mathrm{~Hz}, \mathrm{SCH}_{2}\right)$; $4.35(3 \mathrm{H}, \mathrm{s}, 1-\mathrm{Me})$; $4.90\left(1 \mathrm{H}, \mathrm{s}, 4^{\prime}-\mathrm{H}\right) ; 7.32-$ $8.87\left(9 \mathrm{H}, \mathrm{m}, 2^{\prime}-\mathrm{C}_{6} \mathrm{H}_{5}\right.$ and $\left.4-\mathrm{C}_{6} \mathrm{H}_{4} \mathrm{~N}\right) ; 10.16(1 \mathrm{H}, \mathrm{s}, \mathrm{NH})$. Found, \%: C 50.31; $\mathrm{H}$ 4.16; N 6.87. Calculated for $\mathrm{C}_{25} \mathrm{H}_{26} \mathrm{IN}_{3} \mathrm{O}_{4} \mathrm{~S}, \%$ : C 50.77; H 4.43; N 7.10.

\section{RESULTS AND DISCUSSION}

In continuation of search for biologically active compounds, we have synthesized new [3,4']bipyridines - ethyl 6'-ethoxycarbonylmethylsulfanyl1',2',3',4'-tetrahydro-[3,4'] bipyridine-3'-carboxylate 3 , the corresponding 1',4'-dihydro[3,4']bipyridine 4 and investigated their transformations by treatment with $\mathrm{KOH}$, acetic acid and iodomethane.

Piperidinium 5'-cyano-3'-ethoxycarbonyl-2'-hydroxy-2'-phenyl-1',2',3',4'-tetrahydro[3,4']bipyridine-6'-thiolate (1) has been obtained by three-component condensation of ethyl benzoylacetate, 3-pyridinecarboxaldehyde, 2-cyanothioacetamide and piperidine with $72 \%$ yield [12]. It is worth to mention that application of N-methylmorpholine instead of piperidine leads to the corresponding 1',4'-dihydrobipyridine-6'-thiolate [16]. Alkylation of 2'-hydroxy-1',2',3',4'tetrahydro[3,4']bipyridine-6'-thiolate 1 bearing many nucleophilic reaction centres $\left(\mathrm{O}, \mathrm{S}, \mathrm{N}(1), \mathrm{N}\left(1^{\prime}\right)\right.$ and $\left.\mathrm{C}\left(5^{\prime}\right)\right)$ under mild reaction conditions with ethyl bromoacetate proceeds preferably at the sulfur atom giving rise to ethyl 5'-cyano-6'-ethoxycarbonylmethylsulfanyl-2'-hydroxy-2'-phenyl-1',2',3',4'-tetrahydro[3,4']bipyridine-3'-carboxylate (3).

Usually, the corresponding 1,4-dihydropyridines are easily prepared by dehydration of 2-hydroxy-1,2,3,4-tetrahydropyridines, but treatment of 2'-hydroxy-1',2',3',4'-tetrahydro[3,4'] bipyridine 3 with $\mathrm{HCl} / \mathrm{EtOH}$ similarly as mentioned in [17] leads to the complicated reaction mixture, which contains products of ring cleavage and hydrolysis. By treatment of bipyridine 3 with $\mathrm{KOH} / \mathrm{H}_{2} \mathrm{O}$, the desired 6-hydroxy-4,5,6,7-tetrahydrothieno[2,3-b]pyridine 6 was not isolated from the complicated reaction mixture.

Alkylation of betaine 2 [12] (prepared by treatment of 1',2',3',4'-tetrahydrobipyridine-6'-thiolate 1 with $\mathrm{HCl} / \mathrm{EtOH}$ ) with ethyl bromoacetate in the presence of stoichiometric amount of piperidine gave crude ethyl 6'-ethoxycarbonylmethylsulfanyl-1',4'-dihydro[3,4']bipyridine-3'-carboxylate 4 which did not crystallize from reaction mixture. The treatment of the latter with $\mathrm{KOH} / \mathrm{H}_{2} \mathrm{O}$ gave the desired diethyl 3-amino-6-phenyl-4-(pyridin-3-yl)-4,7-dihydrothieno[2,3-b]pyridine-2,5-dicarboxylate (5) with $12 \%$ yield (79\% yield of compound $\mathbf{5}$ was reached, when pure 1',4'-dihydrobipyridine 4 was used), but subsequent treatment of the remaining reaction mixture with acetic acid gave pure 1',4'-dihydrobipyridine 4 ( $5 \mathrm{~min}$ reflux) and the product of intramolecular acylation - ethyl 8-cyano-3-oxo-5-phenyl-7-(pyridin-3-yl)-2,3-dihydro-7H-thiazolo[3,2-a]pyridine-6-carboxylate (7) (5 h reflux). By treatment of ethyl 1',4'dihydro[3,4']bipyridine-3'-carboxylate 4 with iodomethane in dry acetone, dihydro[3,4']bipyridinium salt $\mathbf{8}$ was formed. The low yield of 1',4'-dihydrobipyridine 4 (complicated isolation) in the case when betaine 2 was treated with stoichiometric amount of ethyl bromoacetate is, obviously, explained by competitive alkylation both at $\mathrm{S}$ atom and $\mathrm{N}(1)$ atom of the pyridine ring. 
The structures of the synthesized compounds were confirmed by spectroscopic methods. In the IR spectra, the characteristic absorption bands of $\mathrm{C} \equiv \mathrm{N}$ group are observed for 1',2',3',4'-tetrahydrobipyridine 3, 1',4'-dihydrobipyridines $\mathbf{4 , 8}$ and $7 \mathrm{H}$-thiazolo[3,2-a]pyridine 7 at $2198-2206 \mathrm{~cm}^{-1}$. Absorption bands of $\mathrm{C}=\mathrm{O}$ groups of the compounds 3-5 and 7 are in agreement with the type of conjugation of $\mathrm{C}=\mathrm{O}$ groups. The doublets in the ${ }^{1} \mathrm{H}$ NMR spectrum of compound 3 with $J_{3,4}=12.1 \mathrm{~Hz}$ according to [18] confirm trans-diaxial configuration of the $3^{\prime}-\mathrm{H}$ and $4^{\prime}-\mathrm{H}$ protons. In the case of $1^{\prime}, 4^{\prime}$-dihydrobipyridines 4, 8, 4,7-dihydrothieno[2,3-b]pyridine 5 and 7H-thiazolo[3,2-a]pyridine 7 , the characteristic 4 '- $\mathrm{H}, 4-\mathrm{H}$ or $7-\mathrm{H}$ proton signals at $4.58-5.18 \mathrm{ppm}$ are observed.

\section{CONCLUSIONS}

Ethyl 5'-cyano-6'-ethoxycarbonylmethylsulfanyl-2'-hydroxy-2'-phenyl-1',2',3',4'tetrahydro[3,4']bipyridine-3'-carboxylate (3) and the corresponding ethyl 1',4'dihydro[3,4']bipyridine-3'-carboxylate (4) as potential cardiovascular agents have been prepared by alkylation of $2^{\prime}$-hydroxy-1',2',3',4'-tetrahydro[3,4']bipyridine-6'-thiolate 1 or betaine 2 with ethyl bromoacetate. The treatment of ethyl 5'-cyano-6'-ethoxycarbonylmethylsulfanyl-2'-phenyl-1',4'-dihydro[3,4']bipyridine-3'-carboxylate (4) with $\mathrm{KOH} / \mathrm{H}_{2} \mathrm{O}$ gave diethyl 3-amino-6-phenyl-4(pyridin-3-yl)-4,7-dihydrothieno[2,3-b]pyridine-2,5-dicarboxylate (5), but subsequent treatment of the remaining reaction mixture with acetic acid excess gave ethyl 8-cyano-3-oxo-5-phenyl-7-(pyridin-3-yl)-2,3-dihydro-7H-thiazolo$[3,2-a]$ pyridine-6-carboxylate (7) - the product of intramolecular acylation. Compounds 4, 5 and 7 have been prepared by making use of one-pot synthesis method. Alkylation of [3,4']bipyridine 4 with iodomethane gave 1',4'-dihydro[3,4']bipyridin-1-ium iodide 8 .

\section{REFERENCES}

1. Krauze, A.A., Vitolinya, R. O., Romanova, M.R. and Dubur, G.Ya. (1988). Synthesis and cardiovascular activity of 4-substituted 2-alkylthio-1,4-dihydropyridines. Pharm. Chem. J., 22(8), 627-631.

2. Krauze, A., Pelchers, J., Vitolina, R., Selga, M., Petersone, I., Kalme, Z., Kimenis, A., Duburs, G. (1988). Preparation of 2-(methylthio)-3-cyano-4-(2-difluoromethoxyphenyl)-6phenyl-1,4-dihydropyridine as antihypertensive. Worldwide patent, WO8803529, C.A., $1989,111,153632 t$.

3. Krauze, A., Baumane, L., Sile, L., Chernova, L., Vilums, M., Vitolina, R., Duburs, G., Stradins, J. (2004). Synthesis, cardiovascular activity, and electrochemical oxidation of nitriles of 5-ethoxycarbonyl-2-methylthio-1,4-dihydropyridine-3-carboxylic acid. Chem. Heterocycl. Comp., 40(7), 876-887.

4. Krauze, A.A., Odynets, A.G., Verreva, A.A., Germane, S.K., Kozhukhov, A.N., Dubur, G.Ya. (1991). Synthesis and hepatoprotectant activity of 5-carbamoyl- and 5-acetyl-2-alkylthio-6methyl-4-aryl-3-cyano-1,4-dihydropyridines. Pharm. Chem. J., 25(7), 477-481.

5. Kirule, L.E., Krauze, A. A., Velena, A.Kh., Antipova, D.Yu., Arnitsane, G.Ya., Vutsina, I.A., Dubur, G. Ya. (1992). Synthesis, antioxidant activity and membrane binding of 4,5,6-substituted 2-methylthio-3-cyano-1,4-dihydropyridines. Pharm. Chem. J., 26(1112), 865-869.

6. Tirzite, D., Krauze, A., Zubareva, A., Tirzitis, G., Duburs, G. (2002). Synthesis and antiradical activity of 5-acetyl-2-alkylthio-4-aryl-6-ethyl-1,4-dihydropyridine-3-carboxylic acid nitriles. Chem. Heterocycl. Comp., 38(7), 795-800.

7. Alousi, A.A., Canter, J.M., Montenaro, M.J., Fort, D.J. and Ferrari, R.A. (1983). Cardiotonic activity of milrinone, a new and potent cardiac bipyridine, on the normal and failing heart of experimental animals. J. Cardiovasc. Pharmacol., 5, 792-803. 
8. Honerjager, P. (1991). Pharmacology of bipyridine phosphodiesterase III inhibitors. Am. Heart J., 121(6), 1939-1944.

9. Zewail, A.M., Nawar, M., Vrtovec, B., Eastwood, C., Kar, B., Delgado, R.M. (2003). Intravenous milrinone in treatment of advanced congestive heart failure. Texas Heart Inst. J., 30, 109-113.

10. Kwak, Y.L., Oh, Y.J., Kim, S. H., Shin, H.K., Kim, J.Y., Hong, Y.W. (2004). Efficacy of preemptive milrinone in off-pump coronary artery bypass surgery: comparison between patients with a low and normal pre-graft cardiac index. Eur. J. Cardio-Thoracic Surgery, 26, 687-693.

11. Schreiber, K., Melvin, L. (2005). 1,4-Dihydropyridine compounds, pharmaceutical compositions, and methods for the treatment of cardiovascular disease. World Intellectual Property Organization patent, WIPO 2005/042487 A1; C.A., 2005, 142, 457082g.

12. Krauze, A.A., Garaliene, V.N., Dubur, G.Ya. (1992). Synthesis, properties, and cardiotonic activity of some 2-carbamoylmethylthio-6-phenyl-5-ethoxycarbonyl-3-cyano-4-[pyrid-3-yl]pyridines and their hydrogenated analogs. Pharm. Chem. J., 26(5), 411-415.

13. Krauze, A. Viļums, M., Sīle, L., Duburs, G. (2009). Alternative products in one-pot reaction of benzylidene-malononitrile, thiocarbamoylacetamide and halomethyl ketones. Heterocycl. Comm., 15(4), 239-244.

14. Bossert, F., Meyer, H., Wehinger, E. (1981). 4-Aryldihydropyridine, eine neue klasse hochwirksamer calcium-antagonisten. Angew. Chem., 93(9), 755-763.

15. Kažoka, H., Krauze, A., Viļums, M., Černova, L., Sīle, L., Duburs, G. (2007). Synthesis and investigation of the stability of esters of 6'-carbamoylmethylthio-5'-cyano-1',4'-dihydro-3,4'and-4,4'-bipyridine-3'-carboxylic acids 1 . Esters of 6'-carbamoylmethylthio-5'-cyano-1',4'dihydro-3,4'-bipyridine-3'-carboxylic acids. Chem. Heterocycl. Comp., 43(1), 50-57.

16. Dyachenko, V.D. (2006). Preparative route to N-methylmorpholinium 3-cyano-5-(ethoxycarbonyl)-6-phenyl-4-(3-pyridyl)-1,4-dihydropyridine-2-thiolate and its 2-(alkylthio) derivatives. Ukr. Khim. Zhurn. (russian edition), 72(3-4), 96-100; C.A., 2006, 145, 505299u.

17. Krivokolysko, S.G., Dyachenko, V.D., Chernega, A.N., Litvinov, V.P. (2001). Synthesis and properties of ammonium 5-benzoyl-4-(2-chlorophenyl)-3-cyano-6-hydroxy-6-phenyl1,4,5,6-tetrahydropyri-dine-2-thiolates. Chem. Heterocycl. Comp., 37(6), 727-732.

18. Rubio, M.J., Seoane, C., Soto, J. L., Susaeta A. (1986). Synthesis of heterocyclic compounds. L: Preparation of ethyl 2,4-diaryl-5-cyano-1,6-dihydro-6-thioxo-3-pyridinearboxylates from ethyl $\alpha$-benzoylcinnamates. Lieb. Ann. Chem., 1, 210-219.

\title{
DAL̦ĒJI HIDRĒTO ([3,4']BIPIRIDĪN-6'-ILSULFANIL)ETIKSSKĀBES ETILESTERU SINTĒZE UN İPAŠĪBAS
}

\author{
A. Krauze, Z. Andžāns, G. Duburs
}

\section{K O P S A V I L K U M S}

5'-Ciano-6'-etoksikarbonilmetilsulfanil-2'-fenil-2'-hidroksi-1',2',3',4'-tetrahidro[3,4']bipiridīn-3'-karbonskābes etilesteris (3) un atbilstošais 1',4'-dihidro[3,4']bipiridīn-3'-karbonskābes etilesteris (4) kā potenciāli kardiovaskulārie ağenti iegūti, alkilējot 2'-hidroksi-1',2',3',4'-tetrahidro[3,4']bipiridīn-6'-tiolātu (1) vai betaīnu 2 ar brometiķskābes etilesteri. Iedarbojoties uz 5'-ciano-6'-etoksikarbonilmetilsulfanil-2'-fenil-1',4'-dihidro[3,4']bipiridīn-3'-karbonskābes etilesteri (4) $\operatorname{ar} \mathrm{KOH} / \mathrm{H}_{2} \mathrm{O}$, iegūts 3-amino-6-fenil-4-(piridin-3-il)-4,7-dihidrotiēno[2,3-b]piridīn-2,5-dikarbonskābes dietilesteris (5), bet reakcijas atlikumu vārot 5 stundas etiķskābē, iegūts 8-ciano-5-fenil-3-okso-7-(piridin-3-il)-2,3-dihidro-7Htiazolo[3,2-a]piridīn-6-karbonskābes etilesteris (7), kas ir savienojuma 4 iekšmolekulārās acilēšanas produkts. Savienojumi 4,5 un 7 iegūti, lietojot vienreaktora sintēzes metodi. Alkilējot [3,4']bipiridīnu (4) ar jodmetānu, iegūts attiecīgais 5'-ciano-3'-etoksikarbonil-6'-etoksikarbonilmetilsulfanil-2'-fenil-1-metil1',4'-dihidro[3,4']bipiridīn-1-ija jodīds (8). 